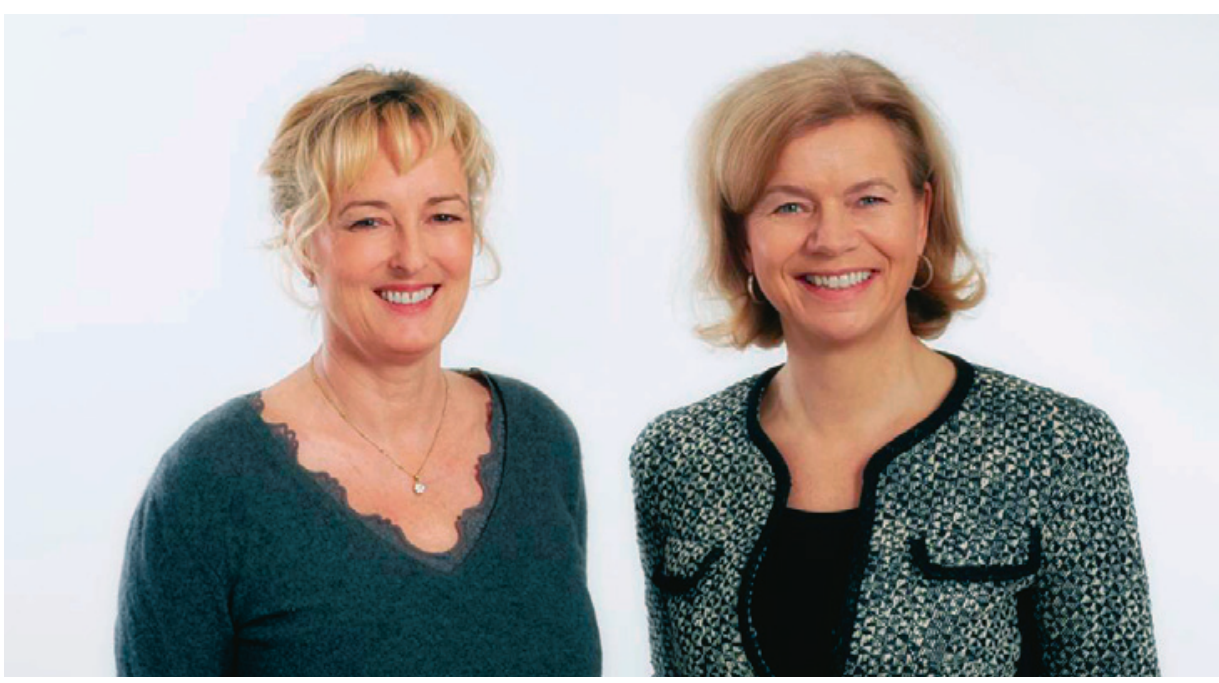

Sisteforfatter Malin Eberhard-Gran (til venstre) og førsteforfatter Elisabeth Krefting Bjelland. Foto: Ole Walter Jakobsen

\title{
Gir hormonell prevensjon øt risiko for bekkenløsning?
}

Bruk av kombinasjonspiller som prevensjon øker ikke risikoen for utvikling av bekkenleddssmerter under senere svangerskap. Derimot kan det være en mulig sammenheng mellom rene progestinpreparater og bekkenløsning.

Bekkenleddssmerter i svangerskapet er vanlig, men årsakene er ukjente. Slike smerter avtar som regel kort tid etter fødselen, noe som tyder på at hormonelle faktorer er medvirkende. Noen, men ikke alle, studier har vist at tidligere bruk av hormonell prevensjon har betydning for utvikling av bekkenleddssmerter. I en fersk norsk studie ble sammenhengen mellom hormonell prevensjon før svangerskapet og utvikling av bekkenleddsmerter under det undersøkt (1).

Studien omfattet over 90000 svangerskap i den norske mor-og-barn-undersøkelsen. Kvinnene besvarte et spørreskjema i svangerskapsuke 17 og 30. Det var blant annet spørsmål om bruk av hormonell prevensjon, slik som p-piller, minipiller, hormoninjeksjoner og hormonspiral, og om smerter i bekkenet. Bekkenleddssmerter ble definert som smerter over symfysen og begge iliosakralleddene i svangerskapsuke 30 .

Bekkenleddssmerter inntil svangerskapsuke 30 hadde ingen sammenheng med bruk av p-piller det siste året før svangerskapet. Kvinner som hadde brukt hormonspiral siste år før svangerskapet (oddsratio 1,20; $95 \%$ KI 1,11-1,31) og kvinner som rapporterte langvarig bruk av minipiller (oddsratio 1,49; $95 \%$ KI 1,01-2,20), hadde derimot en lett økt risiko for å utvikle bekkenleddssmerter.

- Resultatene tyder på at kombinasjonspiller kan brukes uten fare for å utvikle bek- kenleddssmerter i svangerskapet, sier postdoktor Elisabeth Bjelland, som er studiens førsteforfatter.

- Det er for tidlig å gi kliniske råd om bruk av hormonspiral og minipiller. Vi trenger flere studier om sammenhengen mellom progestinpreparater og svangerskapsrelaterte bekkenleddssmerter, sier Bjelland.

\section{Forskning om bekkenløsning}

Studien er en del av en større satsing for å kartlegge årsaker til og konsekvenser av bekkenløsning. Prosjektet er et samarbeid mellom Nasjonalt folkehelseinstitutt og Akershus universitetssykehus. Elisabeth K. Bjelland er postdoktor ved Forskningssenteret, Akershus universitetssykehus. Medforfattere er Siri Vangen, Oslo universitetssykehus, Hedvig Nordeng, Universitetet i Oslo, og Per Kristiansson, Uppsala universitet. Prosjektleder og sisteforfatter er professor Malin Eberhard-Gran ved Akershus universitetssykehus.

\section{Kari Tveito}

Tidsskriftet

\section{Litteratur}

1. Bjelland EK, Kristiansson $\mathrm{P}$, Nordeng $\mathrm{H}$ et al. Hormonal contraception and pelvic girdle pain during pregnancy: a population study of 91,721 pregnancies in the Norwegian Mother and Child Cohort. Hum Reprod 2013; 28: 3134-40.
Ordforklaringer

Bekkenløsning: Bekkenløsning rammer omtrent hver femte kvinne og er den viktigste årsaken til sykmelding i svangerskapet. Tilstanden medfører ofte dårlig fysisk funksjon noen gravide må bruke krykker. Årsaken er ukjent. Bekkenløsning har store samfunnsøkonomiske konsekvenser.

Kombinasjonspiller: Prevensjonsmiddel som inneholder både østrogener og progestin. Kombinasjonspiller er den vanligste formen for hormonell prevensjon hos yngre kvinner.

Progestinpreparater: Hormonspiral, minipiller og hormoninjeksjoner er rene progestinpreparater.

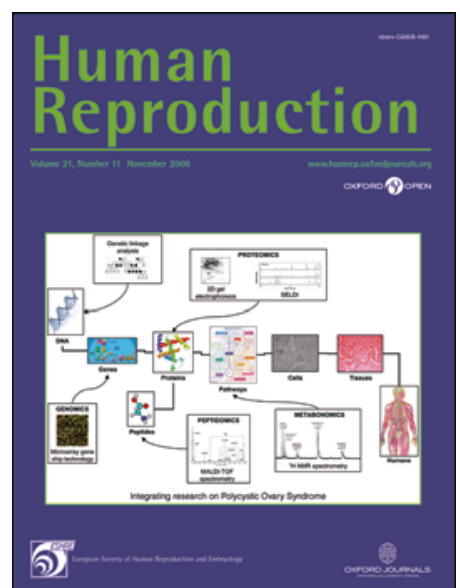

Artikkelen ble publisert i november 2013 i Human Reproduction, som er et av de fremste tidsskriftene innen reproduktiv biologi og obstetrikk og gynekologi 